\title{
Analysis of the potential use of Trombe walls in Brazil: design recommendations
}

\author{
Fernando Antonio de Melo Sá Cavalcanti and Rosana Maria Caram \\ Universidade Federal de Alagoas and Universidade de São Paulo, Brazil
}

Received: 12 May 2020 / Accepted: 6 July 2020

\begin{abstract}
In this paper, the thermal performance of a standard environment was evaluated based on the use of a Trombe wall with different configurations and types of use, as the potential for using this passive strategy is still little studied in Brazil. This device is capable of absorbing energy from solar radiation by heating the air in this greenhouse and this heated air can be directed to the interior or exterior of the building depending on the purpose. This air can be used to heat the room or cool it by means of natural ventilation. The analysis of this research was based on a series of computer simulations using the EnergyPlus software, version 7.0 in order to quantify and classify the thermal performance of a standard environment equipped with this component, under the various construction configurations. Both for heating and cooling environments. The use of Trombe walls improved the thermal comfort of users in buildings located in Brazil, depending on the climate where they are located, promoting natural ventilation and passive solar heating, allowing the potential of this device to be investigated in the most diverse Brazilian regions.
\end{abstract}

Keywords: Trombe walls / Brazilian climates / EnergyPlus

\section{Introduction}

Trombe walls have great potential in promoting thermal comfort in a building, since they can be used with the intention of taking advantage of natural ventilation, solar heating and thermal inertia [1]. The average solar radiation in the Brazilian territory $\left(5 \mathrm{~kW} \mathrm{~h} / \mathrm{m}^{2}\right.$ day) [2], is practically equal to the maximum irradiation value observed in the European continent, which is approximately $5.5 \mathrm{~kW} \mathrm{~h} / \mathrm{m}^{2}$. day [3], where there is a large investment, both governmental and private, in the use of solar energy.

About of these aspects, it can be said that the architect should always seek to adapt the buildings to the climate of the place where it will be installed and the Walls of MichelTrombe, or "Trombe Walls", as they are known, are presented in this paper as a alternative for architectural design, although its potential for use in Brazil is still little investigated.

Figure 1 illustrates the composition of this construction system in order to facilitate the understanding of its parts and its functioning process. In this scheme it is possible to observe the glazed surface (a), with thickness generally between 02 and 06 millimeters, which will be responsible for promoting the greenhouse effect in the air chamber

\footnotetext{
* e-mail: fernando.antonio@fau.ufal.br
}

(b) between the glass and the internal wall with high thermal mass (c). This wall is usually presented with high thermal absorption, in order to optimize the accumulation of heat in the air chamber and consequently the heating of the air in this region of the analyzed component. This wall has two openings for air circulation (d), one lower for the entry of cold air that will be heated in the air chamber due to the greenhouse effect and the other upper for the passage of heated air to the internal environment (e) that will be occupied by users and will become the object of study of this paper regarding the thermal performance of buildings. The internal environment has an opening for the entry of air (f) on the opposite side to the face where the trombe wall is located, allowing the renewal of air in this space and removal of the heated air when this procedure is necessary.

The glazed surface may also have an opening in its upper region (a.1) to exhaust the heated air, making it possible to take advantage of natural ventilation in the hottest months of the year.

The configuration of the openings will define the purpose of using a Trombe wall, whether for heating or cooling. This configuration variation can occur through the interference of the user who will define his comfort needs or through automated means, enhancing its use in times when there is a greater need.

To take advantage of passive heating through the Trombe wall, the opening of the glazed surface must not 


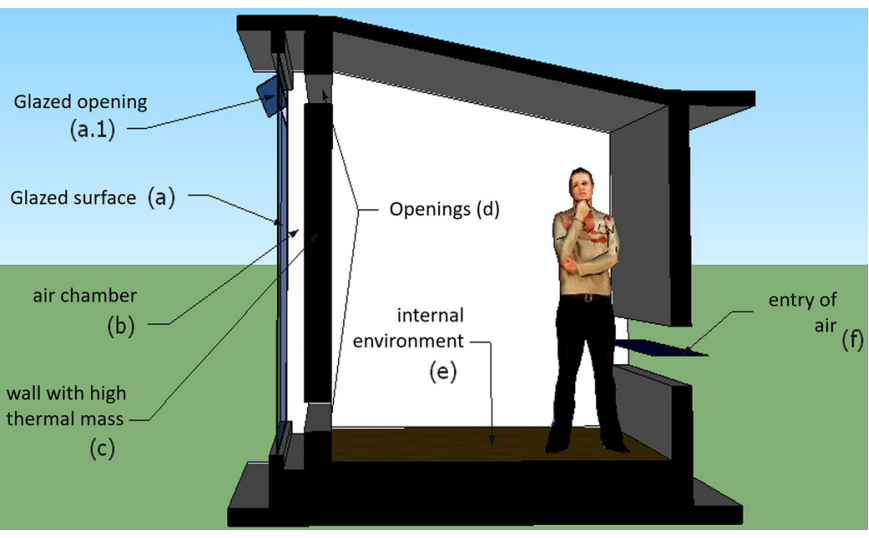

Fig. 1. Configuration of a Trombe wall.

allow heated air to pass through, which in turn must be released into the internal space by the upper opening of the wall with high thermal inertia, heating it and returning to the air chamber through the lower opening, restarting the cycle [4].

To promote ventilation, the wall with a high thermal mass must have only the lower opening allowing air circulation and the outlet opening located on the glass surface must also allow air to pass. The outside air enters through another opening in a different wall and the indoor air, which is warmer, exits through the Trombe wall [5].

The first researcher to describe the concept of a Trombe Wall was an American named E. L. Morse in an 1881 patent [6]. Also known as Solar wall or Thermal storage wall, this idea was repatented in the 70 s by the French inventor and engineer Felix Trombe and by the architect Jacques Michel [7].

Since then, several studies have been carried out in various parts of the world in order to investigate the thermal performance of buildings equipped with this architectural device, [8-10] for Brazil, few studies were found in the bibliography on the subject, such in [11] where measurements were made in loco to evaluate the performance of a Trombe wall for the climate of the South of the country. This system had bottles filled with water to assist in thermal storage, a thermal delay of 4-5 hours was observed between the peak of radiation and the peak of heat accumulated in the Trombe wall [12-15].

Trombe walls have been simulated on computers since their resurgence in the 1970s. In the first models, a thermal Network with several "nodes" was used to simulate a Trombe wall [16]. A series of thermal simulation programs are capable of modeling Trombe walls, including BLAST, DOE-2, TRNSYS, SUNREL and ESP-r [6], however, for this paper, we opted to paper with the Energyplus software for simulating the thermal performance of buildings equipped with a Trombe wall because it is a software that is widespread in the energy efficient building market and considered one of the best today for being free, in addition to being able to simulate with all internal and thermal loads climatic variables of the location where the building will be inserted. For this paper, version 7.0 software was used.
This research has as objective to investigate the potential of the use of trombe walls on the thermal performance of buildings, for the different Brazilian climates, thus contributing to the establishment of bases and design recommendations for the conception of architectural projects in Brazil, from the implantation of a trombe wall with different configurations in each of the eight Brazilian bioclimatic zones; determining which perform better for obtaining thermal comfort in buildings located in Brazil and thus contribute to the establishment of bases and recommendations for the design of projects that adopt this system in Brazilian climates.

\section{Methodoogy}

This methodology was based on parametric studies obtained from computer simulations, using the EnergyPlus $(\mathrm{E}+)$ software, internationally considered as one of the best software today, in order to obtain the best configuration of a Trombe wall, making it possible to use this architectural device in buildings built in Brazil. From these simulations it was also possible to evaluate the performance of the buildings analyzed in terms of thermal comfort, verifying the impact that the use of this device can have on buildings located in Brazil.

The Trombe wall was modeled using objects known from EnergyPlus. A special zone was defined in the air chamber between the wall with high thermal inertia and the glazed surface. These are EnergyPlus surfaces. The wall is connected to the main zone as an internal partition. The glass is a very large window that covers much of the outer wall of the area. If a selective surface is used, it must be defined as a material with the relevant thermal properties in defining the construction of the system.

This approach was chosen to take advantage of the existing heat transfer capabilities in $\mathrm{E}+$ and to allow some flexibility for Trombe wall modeling projects. for these simulations, the standard environment with an occupant and a 40W lamp turned on only at night was considered, minimizing the internal thermal loads of this building.

As for the ventilated trombe wall, it was decided to use the AirflowNetwork module. In the module related to natural ventilation, the air flow links (entrances) are determined, the characteristics of the building's surroundings, the opening conditions of the windows and doors and the ventilation conditions. The algorithm allows the creation of control schedules, ventilation availability, among others.

For these simulations, the pressure coefficients were entered directly by the user. Obtaining accurate pressure coefficient data requires considerable effort. At the same time, there is a great offer of "approximate" values from measurements already made in some Research Institutes.

The wind pressure coefficient $(\mathrm{PC})$ indicates the relationship between the dynamic pressure of free wind and the pressures exerted by natural ventilation at different points on the external surfaces of a volume. For buildings, the $\mathrm{PC}$ values depend on the shape, the wind direction and the influence of obstructions such as neighboring buildings, vegetation and local characteristics 


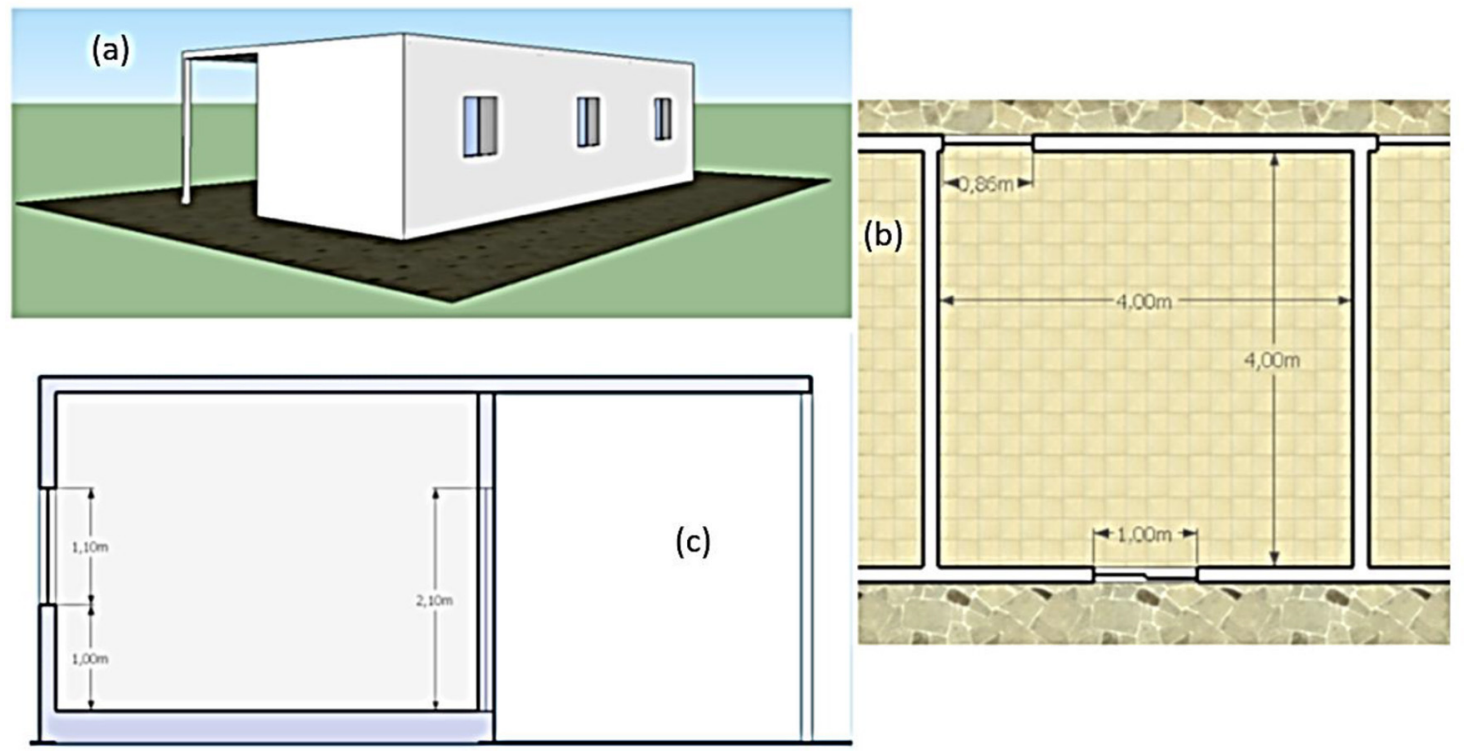

Fig. 2. Perspective (a), Floor plan (b) and Section (c) of the reference model with windows.

of the land and do not depend on the size of the body that receives the pressure, but on the proportions between the dimensions of their faces.

\section{Digital models}

The standard environment has dimensions of $4.00 \times 4.00 \mathrm{~m}$ with a ceiling height of $3.00 \mathrm{~m}$ and has a trombe wall on the facade without shading, oriented to the north, south or west (as described later) with all the walls painted in white (absorbance $a=0.27$ ), with the exception of the wall with high thermal inertia that presents its external surface (surface facing the inside of the air channel of the Trombe wall) painted in black (absorbance $a=0.97$ ).

During the execution of this research, there was also a need to check the feasibility of using this component with regard to a comparison between a conventional model of openings. A window was then dimensioned $1.00 \mathrm{~m}$ wide, $1.10 \mathrm{~m}$ high and 1.00 sill (standard size), with $50 \%$ of this area allowing natural ventilation (which constitutes a sliding window, a typology widely used in buildings constructed in Brazil) and then the performance of this reference environment was compared with an environment with the same dimensions, but with the type of openings investigated in this work (trombe walls), verifying the potential use of this element for heating and mainly promoting the natural ventilationThis environment will be simulated between two other similar volumes, in order to verify the thermal exchanges between the facade and the external environment only through the facades where the openings are located, therefore, the only simulated area was the central room (Fig. 2).

The frame chosen was a sliding window (50\% of the opening area for natural ventilation) as it is a typology widely used in buildings today. In relation to the external wall where the windows were inserted, as in all models, walls with high thermal inertia $(0.45 \mathrm{~m})$ were requested, this thickness was maintained (in addition to the other walls with $0.15 \mathrm{~m}$ ) in order to identify only the influence of absence of the trombe wall and presence of the frame.

The simulations were carried out using the energyplus airflow network module, which best presents the results for the internal temperature taking into account the thermal changes through natural ventilation.

The façade with the Trombe wall was modeled completely exposed to solar radiation, while the opposite façade has a $3.00 \mathrm{~m}$ wide sunscreen, creating a transition space between the interior and the exterior and preventing direct radiation from influencing too much in the heating of the zone to be analyzed, as presented by [17] who proved the efficiency of transition areas in shading during the times of higher temperatures throughout the year.

The perspective of the simulated model in this research is shown in Figure 3, indicating the facades with the Trombe wall and the opposite facade, with shading.

The construction systems adopted for the simulations of this research are described in Table 1, where it is possible to observe the thermophysical properties of the materials used as input data for the EnergyPlus software.

The simulations in this research were performed using the standard building model presented above and the parametric variations for which it is desired to investigate the influence on thermal performance. The varied parameters in this research are presented in Table 2, whose impact of each variable will be analyzed together with the others that also influence its thermal performance.

The area of the glazed surface must be analyzed in order to verify the influence that the variation of this parameter can have on the thermal performance of the building after the adoption of the use of this component with different 


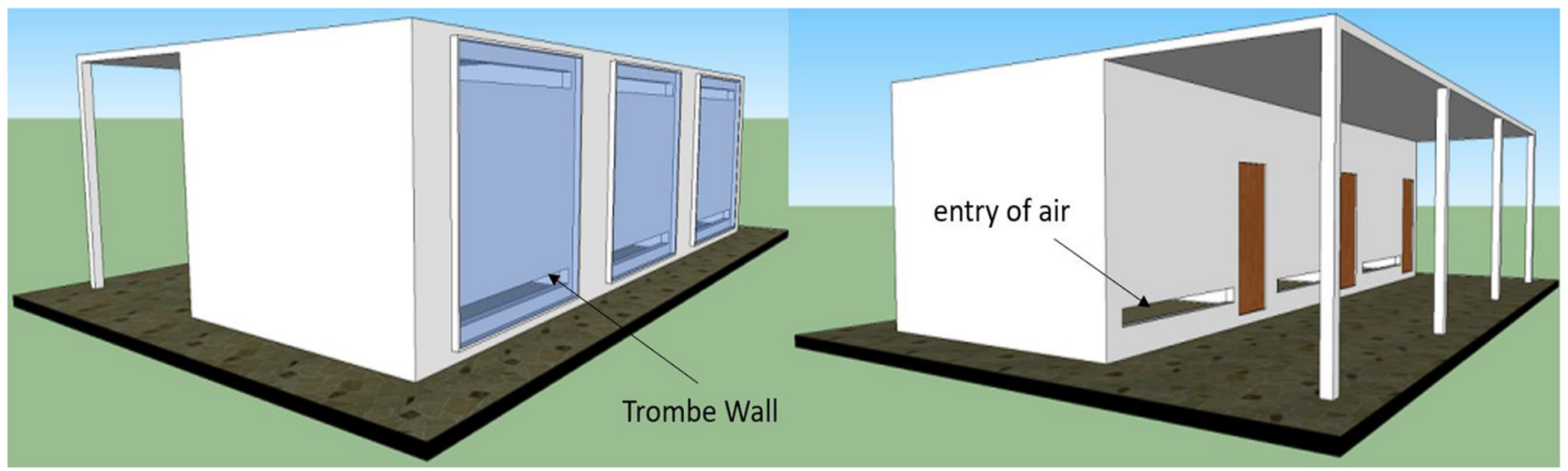

Fig. 3. Digital model.
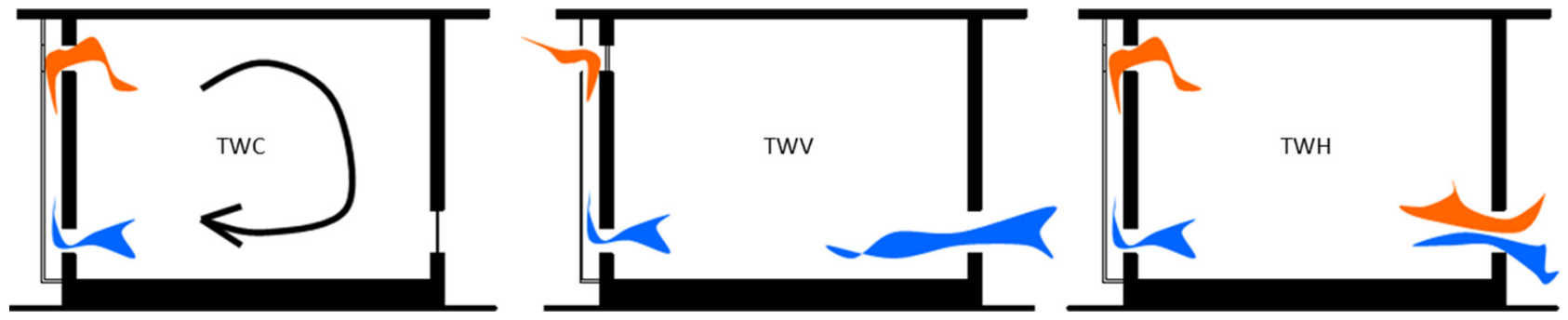

Fig. 4. Tipology of digital model.

configurations, either for heating or cooling. This collecting area varied between $50 \%, 75 \%$ and $100 \%$ of the area on the north face of each environment.

Thus, the width of the trombe wall was varied in this research, while the height of this component remained constant during the simulations so that the height difference between the openings for air circulation was not changed.

The Trombe wall presents, in these simulations, areas for the collection of solar radiation of $6.0 \mathrm{~m}^{2}, 9.0 \mathrm{~m}^{2}$ and $12.0 \mathrm{~m}^{2}$, considering that the facade area of a standard environment (analyzed room) is $12.0 \mathrm{~m}^{2}$, for the widths of $2.0 \mathrm{~m}, 3.0 \mathrm{~m}$ and $4.0 \mathrm{~m}$ respectively and fixed height at $3.0 \mathrm{~m}$.

All possibilities were crossed, resulting in 162 cases for simulation. Three basic situations were considered for the simulations in this research. The first situation aims to provide heating in cold periods, when the two openings (upper and lower) allow the circulation of the air that is heated in this device to the standard environment, however, without renewing the internal air through natural ventilation (considered in the simulations as a model TWC). The second situation promotes natural ventilation, when the glass face of the Trombe wall has an opening for the outlet of air, in addition to considering in this situation the lower opening of the Trombe wall and the entrance opening of the environment allowing the passage of air (Called in this model research - TWV). In the third situation, all openings in the environment will allow air to circulate, promoting heating (in this case, it was called the model - TWH), as shown in Figure 4.
From these considerations and the combination of the possibilities proposed for this research, 486 simulations were carried out for each climatic condition analyzed. It is known, then, that to perform the computer simulations in the EnergyPlus $(\mathrm{E}+)$ software, one of the essential steps is the insertion of the climatic data of the site where the building will be implanted. to 411 Brazilian cities in order to complement the database provided by the software in question [18].

As they are considered more accurate data, as they were obtained from collections in meteorological stations, in this research we chose to use this database in order to consider eight Brazilian climates, one for each bioclimatic zone (BZ) established by NBR-15220/3 (Brazilian Standard of Thermal Performmance in Buildings) [19]. The cities that were simulated in this research are shown in Figure 5.

Brazil is located predominantly in the southern hemisphere, according to the literature found, to project a Trombe wall in these cases, it must be oriented to the North. However, in some cities simulated in this research, with low latitudes, it can be observed that in the summer, when there are longer periods of thermal discomfort due to the need for cooling, the solar path predominantly affects the south facade and, thus, the need arose to evaluate the feasibility of following the literature or to propose a new configuration for the specific Brazilian case.

Another possibility identified was the need to orient the Trombe wall to the west, as this way the device would receive direct radiation throughout the year in the afternoon, in addition to promoting greater protection due to the wall with high inertia and small openings. It is 


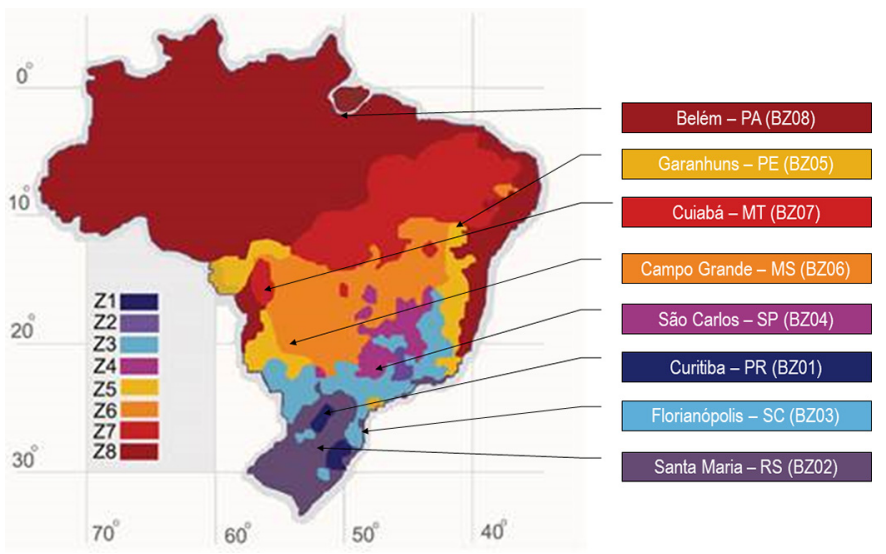

Fig. 5. Brazilian bioclimatic zones and simulated cities.

known that the west facade requires special care as to the possibility of overheating inside the environments.

With these data in hand, the best trombe wall configuration for each Brazilian bioclimatic zone was established, aiming to contribute to providing theoretical support for project professionals who intend to make use of the potential of this device in buildings located in Brazil.

\section{Simulation analysis}

From the computer simulations, it was possible to observe the potential use of Trombe walls for the cases analyzed in this research and to identify the possibility of using this device when subjected to typical Brazilian climates, the results obtained for each construction type adopted will be detailed below.

These simulations were essential to analyze the thermal behavior of the standard building, since from different configurations of Trombe walls, the specific needs for each location were identified, based on the Brazilian bioclimatic zoning.

\subsection{Reference model}

The simulations were carried out using the energyplus airflow network module, which best presents the results for the internal temperature taking into account the thermal changes through natural ventilation.

Table 3 presents the results for the simulations in this reference model for the eight cities considered in this work and from these data, it was possible to identify the feasibility of using the system proposed here in these cities.

A high level of thermal discomfort is then observed, which can result in the user choosing to use active systems, such as air conditioning and mechanical fans to promote thermal comfort, considering that it would cause a monthly cost of electricity. In the case of an underdeveloped country like Brazil, passive strategies become the best choice for cooling and heating buildings and in this case, trombe walls can be an alternative. 
Table 2. Digital model's variables.

\begin{tabular}{|c|c|c|c|c|}
\hline \multicolumn{5}{|c|}{ Variables } \\
\hline $\begin{array}{l}\text { Openings } \\
\text { area } \\
(\%)\end{array}$ & $\begin{array}{l}\text { Wall thickness } \\
\text { with high inertia } \\
(\mathrm{m})\end{array}$ & $\begin{array}{l}\text { Material of the } \\
\text { glazed surface } \\
(-)\end{array}$ & $\begin{array}{l}\text { Glazed surface } \\
\text { area } \\
(\%)\end{array}$ & $\begin{array}{l}\text { Distance: } \\
\text { Wall -Glass } \\
\text { (m) }\end{array}$ \\
\hline 3 & 0.15 & Single glass $3 \mathrm{~mm}$ & 50 & 0.05 \\
\hline 6 & 0.30 & Double glass & 75 & 0.10 \\
\hline & 0.45 & Glass brick & 100 & 0.15 \\
\hline
\end{tabular}

Table 3. Discomfort $\left({ }^{\circ} \mathrm{Ch}\right)$ obtained for the simulations of the reference model.

\begin{tabular}{llll}
\hline & \multicolumn{2}{c}{ DISCOMFORT $\left({ }^{\circ} \mathrm{Ch}\right)$} & TOTAL \\
\cline { 2 - 4 } & COLD & HOT & 23242,96 \\
\hline CURITIBA - PR & 23242,96 & 0,00 & 21830,92 \\
SANTA MARIA - RS & 21768,47 & 62,45048 & 8993,089 \\
FLORIANÓPOLIS - SC & 8991,029 & 2,060344 & 8100,477 \\
SÃO CARLOS - SP & 8083,909 & 16,5672 & 4619,022 \\
GARANHUNS - PE & 4619,022 & 0,00 & 4882,517 \\
CAMPO GRANDE - MS & 4759,624 & 122,8934 & 4054,864 \\
CUIABÁ - MT & 1795,725 & 2259,14 & 80,46026 \\
BELÉM - PA & 0,00 & 80,46026 & \\
\hline
\end{tabular}

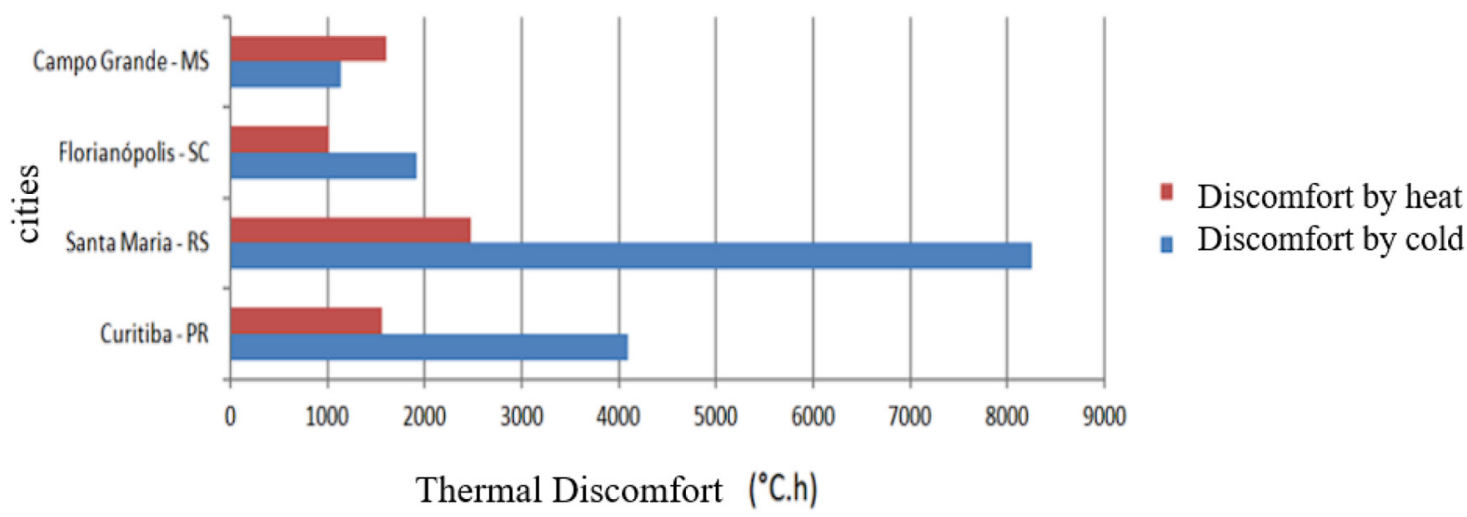

Fig. 6. Total discomfort in ${ }^{\circ} \mathrm{C}$ h due to cold and heat for cities in Campo Grande, Florianópolis, Santa Maria and Curitiba.

\subsection{Thermal performance}

For the typology (TWC), only the renewal of air inside the standard environment by infiltration was considered, promoting heating of the internal environment without the influence of natural ventilation, taking advantage only of the greenhouse effect produced inside the channel of the Trombe wall.

This type of Trombe wall presented the best performance during the year for 04 (four) cities analyzed: Curitiba, Santa Maria, Florianópolis and Campo Grande. However, for each location a specific model showed less total amount of thermal discomfort (heat + cold).

Figure 6 presents a comparison between the annual thermal discomfort for the best models considered in these
04 cities, both by heat and cold, where it is possible to identify that the cities of Curitiba and Santa Maria present greater discomfort than the other cities observed.

The thermophysical properties of the glass used in each model also interfere with its performance, for this type of Trombe wall, it was observed that, with the exception of the city of Campo Grande, which tended to use glass blocks, all other cities request double glazing, mainly due to its high thermal absorption capacity, which although it is close to the values found for the glass block, it presents better performance when used in Trombe walls.

By increasing its glazed area, maintaining the channel thickness, this volume is also increased and more hot air circulates inside the Trombe system reaching the interior of the environment, the heat that remains inside the standard 


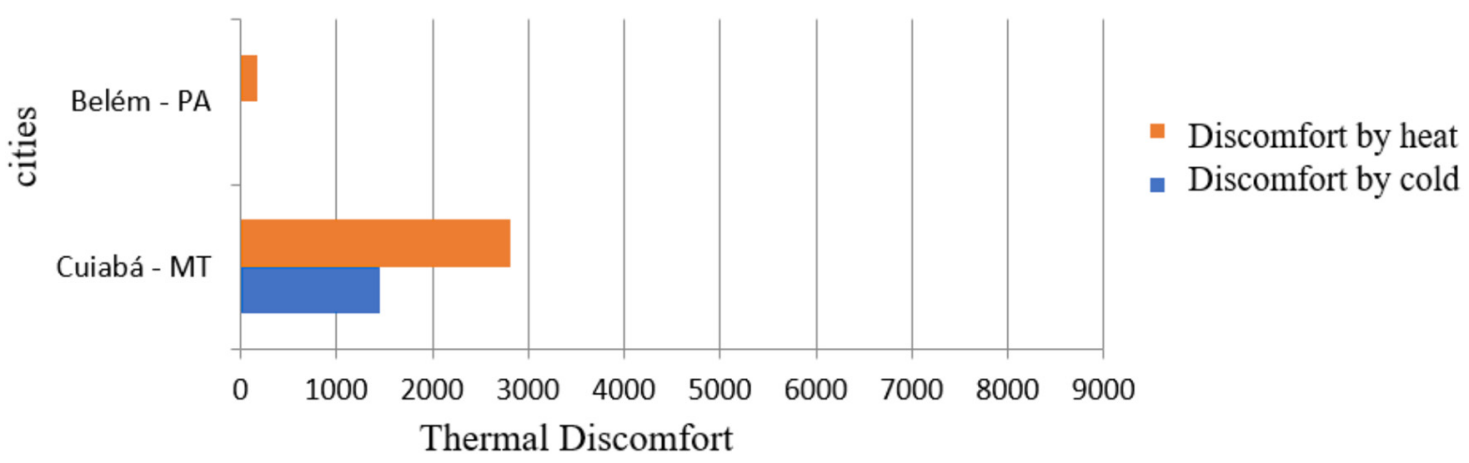

Fig. 7. Total discomfort in ${ }^{\circ} \mathrm{C}$ h due to cold and heat for cities in Cuiabá and Belém.

environment can promote overheating, as it is of a model that prioritizes heating and does not consider natural ventilation.

The closed Trombe wall can be used mainly in cold climates or in climates where heating is the main design recommendation. As this model does not take advantage of natural ventilation, it is usable where outside temperatures are more aggressive and low, preventing this cold air from penetrating the building in order to compromise its thermal performance.

When analyzing the Trombe walls for ventilation, initially a study was made of the possibility of using this typology for the city of Campo Grande, as mentioned earlier, in this way, the models considered in the closed typology as the best ones were identified and it was possible to analyze the potential of use of this typology that promotes natural ventilation, prioritizing the cooling of internal spaces, enabling its combined use, taking advantage of the closed typology in winter and the typology for ventilation in summer.

This ventilated typology also showed favorable results for its use in the cities of Cuiabá and Belém, which are the two hottest cities analyzed in this research. However, there was still a small thermal discomfort.

For the two cities mentioned here, the computational model that presented the best performance was the model with a ventilated Trombe wall with a width of $2.0 \mathrm{~m}(50 \%$ of the facade area covered by this device), $3 \%$ of this area for entrance and exit openings. of the air, span of $0.10 \mathrm{~m}$ and wall of $0.45 \mathrm{~m}$, in addition to closing the collecting surface with double glazing

It can be said then that the ventilated Trombe wall can be an interesting strategy in these cities, especially in cities with a hot and humid climate, where the air temperature is generally lower than the skin temperature, promoting thermal exchanges by convection between humans and air through natural ventilation providing low thermal discomfort, as shown in Figure 7, especially for the city of Belém, where it was not possible to identify discomfort due to cold.

The trombe wall configuration for heating takes advantage of the two strategies mentioned above, as it allows the rooms to be heated and also allows an exchange of the indoor air in the building with the external air.
In the conditions analyzed in this research, this typology was better suited for the cities of São Carlos and Garanhuns. These cities have hot summer and cold winter and require heating in winter and cooling in summer.

For the city of São Carlos, the best model so that total discomfort was minimal was the model with a 4.0 meter thick wall ( $100 \%$ of the facade area), the openings area with $3 \%$ of the area of this device, span thickness of $0.15 \mathrm{~m}$ and wall thickness of $0.45 \mathrm{~m}$ and closing the collecting surface with glass blocks.

This configuration takes advantage of the thermal inertia, which is a design strategy widely used in São Carlos due to the high thermal amplitude of this region and great differences between summer and winter, as this strategy promotes, in addition to thermal damping, a delay in the flow of heat that migrates through building systems with such property.

As for the city of Garanhuns, the model that presented the best thermal performance was similar to the one recommended for the city of São Carlos, differentiating itself by closing the glazed surface that is with double glass.

In this way, the Trombe wall with heating typology, allowing air renewal inside the buildings, presents a good result for locations with cold climates in winter and hot in summer, and in this way it will be possible to minimize thermal discomfort by both cold and heat, as shown in Figure 8 .

\subsection{Orientation of the Trombe wall}

Although the classic literature on the subject studied here mentions that for the southern hemisphere, where all the cities analyzed in this research are located, the Trombe wall must be oriented to the north, some Brazilian cities are located at a low latitude and in these locations it is possible identify that due to the proximity to the equator and high incidence of solar radiation, strategies for refrigeration are the most requested, mainly natural ventilation.

In this case, the Trombe walls facing south were simulated, due to the reasons exposed above and to the west facade, since it is a facade that receives high radiation in the afternoon in all analyzed locations and because it is a facade that projectually it requires care on the part of the design professionals, as it has a high potential to promote 


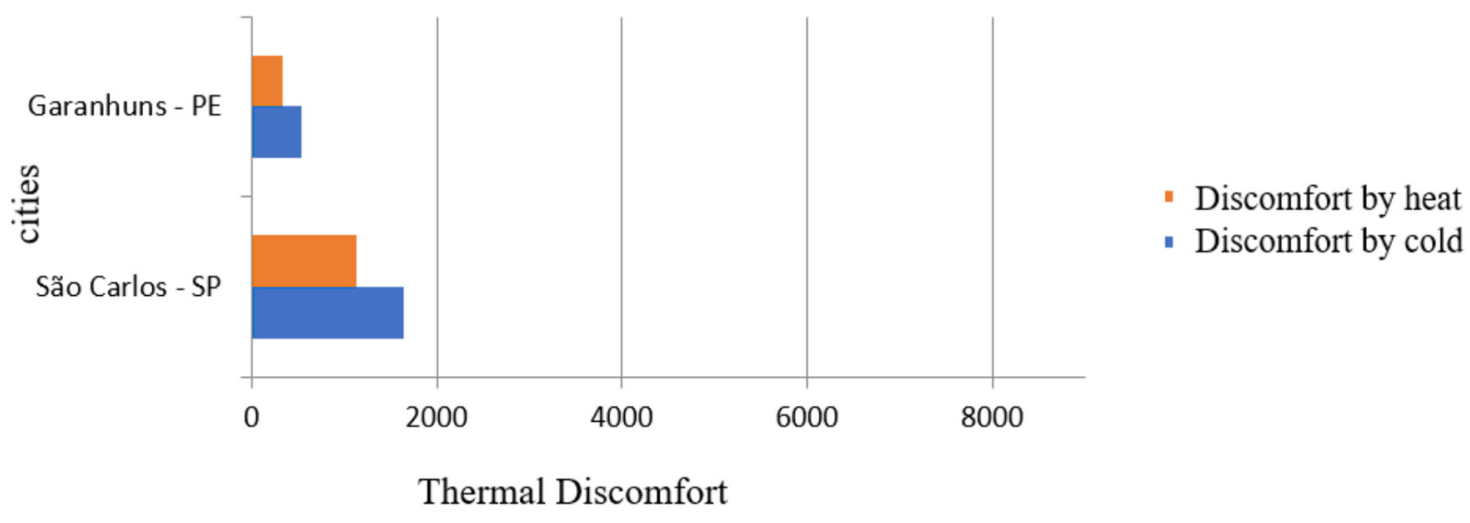

Fig. 8. Total discomfort in ${ }^{\circ} \mathrm{C}$ h due to cold and heat for cities in Garanhuns and São Carlos.

Table 4. Summary of results obtained for the best models in different orientations.

\begin{tabular}{|c|c|c|c|c|}
\hline & & ${ }^{\circ} \mathrm{CH}$ COLD & ${ }^{\circ} \mathrm{CH}$ HEAT & ${ }^{\circ} \mathrm{CH}$ TOTAL \\
\hline \multirow{4}{*}{ CURITIBA - PR } & North Face & 4102,31 & 1568,25 & 5670,56 \\
\hline & South Face & 5695,85 & 198,97 & 5894,81 \\
\hline & West Face & 3192,58 & 2582,45 & 5775,03 \\
\hline & North Face & 8257,23 & 2479,81 & 10737,04 \\
\hline \multirow{3}{*}{ SANTA MARIA - RS } & South Face & 7042,57 & 2547,93 & 9590,50 \\
\hline & West Face & 7891,45 & 2765,57 & 10657,02 \\
\hline & North Face & 1922,89 & 1022,91 & 2945,80 \\
\hline \multirow[t]{3}{*}{ FLORIANóPOLIS - SC } & South Face & 1965,94 & 1447,61 & 3413,56 \\
\hline & West Face & 1783,40 & 1202,70 & 2986,10 \\
\hline & North Face & 1646,51 & 1129,00 & 2775,51 \\
\hline \multirow{3}{*}{ SãO CARLOS - SP } & South Face & 1220,37 & 1393,48 & 2613,85 \\
\hline & West Face & 1609,32 & 1945,47 & 3554,79 \\
\hline & North Face & 538,97 & 388,29 & 927,26 \\
\hline \multirow{3}{*}{ GARANHUNS - PE } & South Face & 682,61 & 207,95 & 890,56 \\
\hline & West Face & 726,88 & 310,79 & 1037,67 \\
\hline & North Face & 233,67 & 219,33 & 453,00 \\
\hline \multirow{3}{*}{ CAMPO GRANDE - MS } & South Face & 1688,80 & 156,19 & 1844,99 \\
\hline & West Face & 1929,49 & 399,56 & 2329,05 \\
\hline & North Face & 1448,79 & 2816,96 & 4265,75 \\
\hline \multirow[t]{3}{*}{ CUIABá - MT } & South Face & 1204,93 & 3774,26 & 4979,19 \\
\hline & West Face & 1277,92 & 4350,33 & 5628,24 \\
\hline & North Face & 0,00 & 178,97 & 178,97 \\
\hline \multirow[t]{2}{*}{ BELéM - PA } & South Face & 0,00 & 191,38 & 191,38 \\
\hline & West Face & 0,00 & 368,63 & 368,63 \\
\hline
\end{tabular}

overheating in indoor spaces. Table 4 presents a summary of the results obtained for the different orientations simulated in this research.

It is also observed that the west façade did not have a good potential for implantation of Trombe walls, because in this case it is a façade that receives solar radiation throughout the year in the afternoon, but in less quantity than the façades that can receive sunlight in some periods of the year throughout the day, in addition to the fact that in Brazil that receives a high level of radiation it can compromise the performance of this component, however other thicknesses for the Trombe wall channel can be investigated later, as this limitation that the facade West presents may be due to the small volume of air that is displaced, especially with regard to natural ventilation to promote cooling in the environments.

\subsection{Trombe wall $\times$ reference model}

When eliminating the trombe wall, there was mainly an increase in cold discomfort when compared with the results obtained in models equipped with this device, with the 


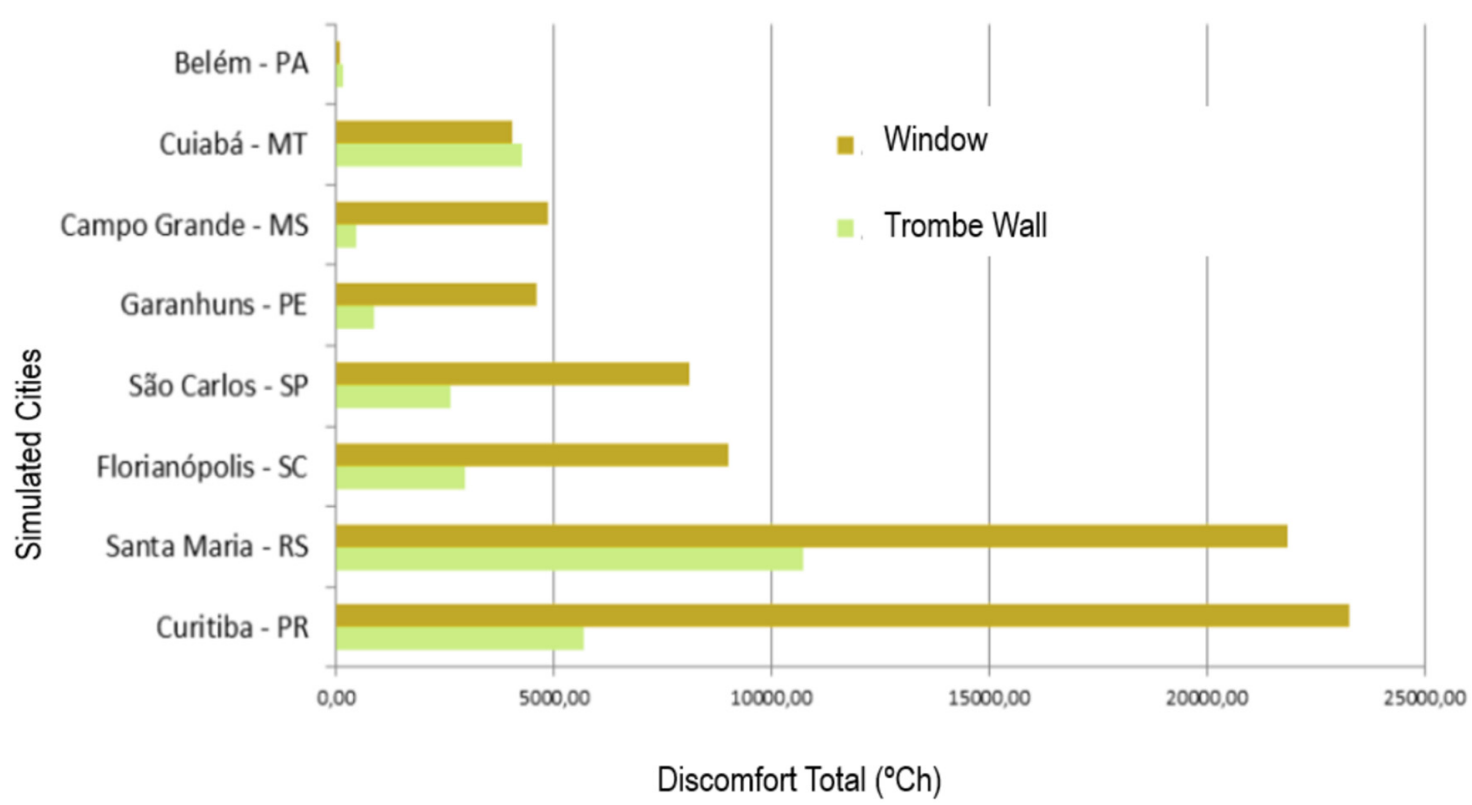

Fig. 9. Comparison between total thermal discomfort for the environment with windows and the best models with Trombe walls in the simulated cities.

exception of the city of Belém, where no cold discomfort was also found.

As for discomfort due to heat, there was a decrease in all cases analyzed. In these situations, the volume of air displaced inside the internal environment is greater than the cases with trombe walls and thus, the heat removed will be greater through the cross ventilation promoted between the door and the window.

It can be said in view of these analyzes that the trombe wall is a device that has great potential for use in Brazil, especially in the winter period, to promote heating of internal spaces, however, in this period, environments with windows may have this element closed, avoiding natural ventilation and improving the thermal performance of the standard environment.

However, when considering total discomfort, the trombe walls proved to be a component that can be used in at least six of the eight cities analyzed, as it is possible to observe in Figure 9 that presents the comparison between these values for the two situations analyzed in this work. (with and without trombe walls) for the best models in each city analyzed.

The cities of Belém and Cuiabá showed better potential for the use of windows when compared to the configurations of trombe walls analyzed in this work, because when inserting a window there is an increase in natural ventilation and a larger volume of air is displaced in the same time interval in the standard environment, however it is up to future studies to analyze a channel thickness within the trombe system greater than those considered here (in this case, the maximum channel thickness was $0.15 \mathrm{~m}$ ).

The other cities located between the Brazilian bioclimatic zones 01 and 06 , presented good potential for the insertion of buildings with trombe walls, because in the total thermal performance, during a simulated reference year, the standard environment presented favorable conditions that corroborate this statement.

\subsection{Design recommendations}

Given the considerations mentioned above, it can be said that for the use of Trombe walls in typical Brazilian climates, some factors must be taken into account, primarily in relation to the wall thickness with high thermal inertia.

In all the cases analyzed in this research, the $0.45 \mathrm{~m}$ thick Trombe wall presented itself as the most adequate model to provide greater thermal comfort to users. This type of wall takes advantage of a high thermal inertia to promote thermal damping and delay, making it possible to obtain milder temperatures indoors and in some cases, making it impossible or difficult for the heat produced by the greenhouse effect in the gap of the Trombe wall to penetrate the building, avoiding discomfort due to heat. Another unanimous variable in all simulated cities was the area of the air inlet and outlet openings, which must be $3 \%$ of the total area of the Trombe wall.

For the other parameters, there was a small variation between the models, as shown in Table 5, where the constructive recommendations are presented, taking into account the parameters analyzed in this research.

When proposing design guidelines for the use of Trombe walls in Brazil, the user's behavior pattern must be taken into account and at the same time allow this device to be controlled manually, allowing greater autonomy for the occupants of buildings equipped with this component.

It is then necessary to compare the models that showed the best performance in each of the simulated cities for each of the typologies presented in this research, because for one typology and another there is no difference in construction 
Table 5. Constructive recommendations for the use of Trombe walls in the cities analyzed.

\begin{tabular}{lllllll}
\hline & Orientation & $\begin{array}{l}(\%) \text { Glazed } \\
\text { Area }\end{array}$ & Openings & $\begin{array}{l}\text { Distance: } \\
\text { Wall }- \\
\text { Glass }(\mathrm{m})\end{array}$ & $\begin{array}{l}\text { Wall Thickness } \\
\text { with High } \\
\text { Inertia }(\mathrm{m})\end{array}$ & $\begin{array}{l}\text { Material of the } \\
\text { Glazed Surface }\end{array}$ \\
\hline CURITIBA - PR & $\mathrm{N}$ & 100 & $3 \%$ & 0,10 & 0,45 & Double glass \\
SANTA MARIA - RS & $\mathrm{N}$ & 100 & $3 \%$ & 0,05 & 0,45 & Double glass \\
FLORIANóPOLIS - SC & $\mathrm{N}$ & 100 & $3 \%$ & 0,15 & 0,45 & Glass brick \\
SãO CARLOS - SP & $\mathrm{S}$ & 100 & $3 \%$ & 0,15 & 0,45 & Glass brick \\
GARANHUNS - PE & $\mathrm{S}$ & 100 & $3 \%$ & 0,15 & 0,45 & Double glass \\
CAMPO GRANDE - MS & $\mathrm{N}$ & 75 & $3 \%$ & 0,10 & 0,45 & Double glass \\
CUIABá - MT & $\mathrm{N}$ & 50 & $3 \%$ & 0,10 & 0,45 & Double glass \\
BELéM - PA & $\mathrm{N} / \mathrm{S}$ & 50 & $3 \%$ & 0,10 & 0,45 & Double glass \\
\hline
\end{tabular}

Table 6. Discomfort for the eight cities analyzed, considering the combined use and user intervention.

\begin{tabular}{|c|c|c|c|c|c|}
\hline & \multicolumn{2}{|c|}{ SUMMER } & \multicolumn{2}{|c|}{ WINTER } & \multirow[b]{2}{*}{ TOTAL } \\
\hline & TIPOLOGY & ${ }^{\circ} \mathrm{Ch}$ Heat & TIPOLOGY & ${ }^{\circ} \mathrm{Ch}$ Cold & \\
\hline CURITIBA - PR & TWV & 4,50 & TWC & 4102,31 & 4106,81 \\
\hline SANTA MARIA - RS & TWV & 403,81 & TWC & 8257,23 & 8661,04 \\
\hline FLORIANóPOLIS - SC & TWV & 74,23 & TWC & 1922,89 & 1997,12 \\
\hline SãO CARLOS - SP & TWV & 76,35 & TWH & 1220,37 & 1296,72 \\
\hline GARANHUNS - PE & TWV & 0,00 & TWC & 195,09 & 195,09 \\
\hline CAMPO GRANDE - MS & TWV & 219,33 & TWC & 233,67 & 453,00 \\
\hline CUIABá - MT & TWV & 2816,96 & TWC & 235,21 & 3052,17 \\
\hline BELéM - PA & TWV & 178,97 & TWV & 0,00 & 178,97 \\
\hline
\end{tabular}

systems, only in terms of use, thus the user you can choose a vented Trombe wall in the summer and a Trombe wall that promotes heating in the winter.

With this analysis, where a combined use of Trombe walls is considered in all cases, the feasibility of using this component in at least six of the eight cities analyzed is confirmed, and it can also be used in the cities of Cuiabá and Belém without major losses for the thermal performance of the internal spaces when compared to these same spaces with windows, as can be seen in the Table 6 .

Given this, it can be said that the climate and the latitude of the city where the trombe wall will be inserted directly influences the facade in which this system should be inserted and oriented, for low latitudes, between $+23.5^{\circ}$ (where they are located the tropics), this component should be oriented towards the facade opposite to that recommended by the classic literature on the subject, except for hot climates located between $-15^{\circ}$ and $-23.5^{\circ}$, when excessive heat can be increased in the summer for the conditions analyzed in this work. These conditions can be better analyzed when investigating other channel thicknesses inside the trombe wall, promoting a greater volume of air displacement.

For cities with hot and humid climates, the model that prioritizes natural ventilation should be used throughout the year, as this is the main design recommendation for these locations, as for regions with hot summer and cold and rainy winter, as is In the case of the city of Garanhuns, in winter the openings of the trombe wall must be closed, allowing only the renewal of the air by infiltration in the winter period and open in the summer, prioritizing natural ventilation.

Cities like São Carlos that present rainy summer and dry winter, in addition to the model that favors natural ventilation in summer, air must be allowed in winter, using the type for heating so that it is possible to obtain a lower index of $\left({ }^{\circ} \mathrm{Ch}\right)$ for cold and heat.

In cities located below the Tropic of Capricorn (latitude $-23.5^{\circ}$ ) the orientation of the system analyzed here should always be on the North façade, as well as general recommendations according to the references cited here.

\section{Conclusions}

This research analyzed the potential of using Trombe walls for typical climates in Brazil. evaluating the thermal performance of the environments where this device was inserted, considering three basic types of operation: closed Trombe walls, to promote natural ventilation and heating through computer simulations using energyplus software. 
These simulations pointed to a good performance of this architectural component in terms of promoting thermal comfort, promoting a thermal damping and delay in the internal temperature of the spaces equipped with this device, in addition to reducing the need to use mechanical systems for heating and cooling.

When identifying among the 3888 simulations carried out the best models for each city analyzed, the following was found:

For the City of Curitiba, the model that best adapted was the Trombe wall that occupies $100 \%$ of the façade area, the openings area with $3 \%$ of the Trombe wall area, they go between the wall and the $0.10 \mathrm{~m}$ glazed surface, $0.45 \mathrm{~m}$ wall thickness and double glazed closure. It was observed that the typology of closed Trombe wall performed better throughout the year, however, considering the user's action throughout this period, it can be said that for the summer, the ventilated Trombe wall provides less discomfort due to heat, while in winter the closed typology provides less discomfort due to cold, by preventing the entry of air at very low temperatures, common at this time of the year.

For the city of Santa Maria, the model that provided the least total discomfort was the Trombe wall with $100 \%$ of the facade area, $3 \%$ of the glazed surface area for the air inlet and outlet openings, with $0.05 \mathrm{~m}$ and $0.45 \mathrm{~m}$ wall thickness, in addition to closing the glazed surface with double glazing.

In the cities of Florianópolis and São Carlos, it is recommended that the Trombe wall be $4.0 \mathrm{~m}$ wide and $3 \%$ of the area of this component as the area of the openings, go between the collecting face and the wall with $0.15 \mathrm{~m}$, wall thickness with $0,45 \mathrm{~m}$ and closing with glass blocks.

The city of Garanhuns also presented the possibility of using this component, and the recommended characteristics for this case are the Trombe wall with a width of $4.0 \mathrm{~m}$ and $3 \%$ of the glazed surface area (double glazing) for the area of the openings and the span between the wall that should be $0.45 \mathrm{~m}$ and the collecting face $0.15 \mathrm{~m}$.

In the warmer regions (cities of Campo Grande, Cuiabá and Belém) the width of the Trombe wall should be reduced, to $75 \%$ of the facade area in Campo Grande and $50 \%$ in the other cities analyzed and the same $3 \%$ of the area of the glass surface for the area of the air inlet and outlet openings, in addition to the thickness of the wall with $0.45 \mathrm{~m}$ and closing of the collecting surface with double glass and thickness of the air channel with $0.10 \mathrm{~m}$.

When considering the possibility of user control, it is suggested that there is no perfect construction system, but that it can be adaptable to the needs of users in order to behave optimally throughout the year.

The use of computer simulations has been shown to be a satisfactory tool in the analysis of the thermal performance of buildings, as it allows the performance of the desired evaluations in a reduced time and with reliability similar to the experimental models. The software used, in addition to providing reliable data, is capable of simulating the building analyzed in this research for a typical reference year in approximately 6 seconds.

Buildings in general must be carefully planned to minimize excessive expenses with lighting and ventilation devices by mechanical means. Architectural devices such as trombe walls should have their potential investigated to assist in the construction of buildings more suited to the regional climate, always aiming at the highest degree of energy efficiency.

Based on these observations, it is intended to improve the awareness that local architecture and the production of buildings must be conducted in such a way that professionals incorporate an appropriate language and their own characteristics, creating a regional typology, giving an identity to the architecture that comes being imported or poorly copied and which loses sight of the most important: the comfort of users. In the face of the energy crisis, it is necessary to design well to reduce energy consumption and take into account the climatic conditions of the environment, applying bioclimatic techniques.

\section{References}

1. A.K. Elsadig, Energy Efficiency in commercial Buildings. Dissertation presented to Master Course of Science Sustainable Engineering, University of Strathclyde, 2004

2. F.R. Martins, E.B. Pereira, S.L. De Abreu, S. Colle, Mapas de Irradiação solar para o Brasil - Resultado do projeto SWERA, In: Simpósio Brasileiro de Sensoriamento Remoto, Goiânia, Brasil, abril de 2005

3. Helioclim - Providing Information on Solar Radiation. European Solar Radiation Atlas. Available from www. helioclim.net/esra/index.html 2004

4. G. Gan, A parametric study of Trombe walls for passive cooling of buildings, Energy Build. 27 (1998)

5. J. Shen, S. Lassue, L. Zalewski, D. Huang, Numerical study on thermal behavior of classical or composite Trombe solar walls, Energy Build. 39 (2007)

6. P.G. Ellis,Development and validation of the unvented trombe wall model in EnergyPlus, Master of Science in Mechanical Engineering in the Graduate College of the University of Illinois at Urbana - Champaign, 2003

7. F. Trombe, U. S. Patent 3,832,992 Naturally air-condittioned dwelling, 1974

8. F. Abbassi, L. Dehmani, Experimental and numerical study on thermal performance of an unvented Trombe wall associated with internal thermal fins, Energy Build. 105, $15(2015)$

9. M.K. Rabani, V. Dehghan, A.A. Faghih, A.K. Faghih, Experimental study of the heating performance of a Trombe wall with a new design, Solar Energy 118, 359-374 (2015)

10. D. Wang, L. Hu, H. Du, Y. Liu, J. Huang, Y. Xu, J. Liu, Classification, experimental assessment, modeling methods and evaluation metrics of Trombe walls, Renew. Sustain. Energy Rev. 124 (2020) 
11. D.F. Figueira, A. Krenzinger, H.A. Vielmo, Daily Performance Evaluation of a Trombe-Michel Wall. In: 17th International Congress of Mechanical Engineering, 2003, São Paulo. Proceedings of COBEM 2003

12. F.S. Cavalcanti, M.A. Lukiantchuki, N. Andrade, R.C. Paiva, R.M. Caram, Parede trombe como estratégia passiva promotora de eficiência energética em São Carlos - SP, in IV Congresso Brasileiro de Eficiência Energética, Juiz de Fora, 2011

13. E. Kruger, E. Suzuki, A. Matoski, Evaluation of a Trombe wall system in a subtropical location, Energy Build. 66, 364-372 (2013)

14. H. Sacht, L. Bragança, M. Almeida, R. Caram, Influence of the position of ventilation modules and types of grids on a modular façade system, Energy Proc. 96, 953-964 (2016)

15. E. Vettorazzi, M. Russi, J.C.P. Santos, A utilização de estratégias passivas de conforto térmico e eficiência energética para o desenvolvimento de uma habitação unifamiliar, in Congresso internadional de Sustentabilidade e Habitação de Interesse Social. Porto Alegra, 2010
16. J.D. Balcomb, G. Barker, C.E. Hancock, An Exemplary Building Case Study of the Grand Canyon South Rim Residence, NREL/TP-550-24767 (National Renewable Energy Laborator, Golden, CO, 1998)

17. V.A. Gomes, L.S. Bittencourt, O papel das galerias no conforto térmico dos espaços de uso público da Avenida Guararapes no Recife, in XI Encontro Nacional e VII Encontro Latino-Americano de Conforto no Ambiente Construído, Búzios, 2011

18. M. Roriz, Arquivos Climáticos de Municípios Brasileiros, Texto para o Grupo de Trabalho sobre Conforto e Eficiência Energética de Edificações, São Carlos, 2012. Available at http://roriz.dominiotemporario.com/doc/Sobre_os_arqui vos_EPW.pdf (accessed Junho de 2012)

19. ABNT, Associação Brasileira de Normas Técnicas. NBR 15220-3. Desempenho Térmico de Edificações - Parte 3: Zoneamento Bioclimático Brasileiro. Rio de Janeiro, 2005

Cite this article as: F.A. de Melo Sá Cavalcanti, R.M. Caram: Analysis of the potential use of Trombe walls in Brazil: design recommendations. Sust. Build. 5, 4 (2020). 